МАТЕМАТИЧНІ МЕТОДИ, МОДЕЛІ ТА ІНФОРМАЦІЙНІ ТЕХНОЛОГІї В ЕКОНОМІЦІ

\author{
УАК 519.85:004.415.2:331.546:33-057.875
}

МАТЕМАТИЧНЕ МОАЕЛЮВАННЯ НА
БАЗІ МАТНСАD ЯК ЗАСІБ
ФОРМУВАННЯ ПРОФЕСІЙНОЇ
КОМПЕТЕНТНОСТІ МАЙБУТНІХ
ЕКОНОМІСТІВ $^{\odot}$

\author{
ЛЕВЧУК О.В., \\ кандидат педагогічних наук, доцент, \\ доцент кафедри математики, фізики та \\ комп'ютерних технологій, \\ Вінницький національний \\ аграрний університет \\ (м. Вінниця)
}

У статті обтрунтовано доиільність впровадження математичного моделювання на базі Mathcad у прочесі формування професійної компетентності майбутніх економістів, визначено основні дидактичні вимоги та досліджено вплив технології на такі складові математичної підготовки як мотиваційно-ціннісна, когнітивна, операційно-діяльнісна, комунікативна.

Доведено, що прочес фундаменталізачї та інформатизачї економічних знань вимагає трансформаиії математичних курсів.

Розглянуто сутність понять «професійна компетентність» та «математична компетентність» майбутніх економістів. Аргументовано, що математична підготовка $\epsilon$ вагомою складовою професійної компетентності.

Проаналізовано вплив математичного моделювання на формування готовності вирімувати професійні завдання як складової професійної компетентності майбутніх економістів.

Виділено основні математичні моделі економічних систем які доџільно розглядати в математичних курсах. Наведено приклади математичного моделювання на базі Mathcad.

Продемонстровано переваги впровадження математичного моделювання в процес професійної підготовки фахівців.

Ключові слова: професійна підготовка майбутніх економістів, математична підготовка, система Mathcad, математичне моделювання в економіці, вища математика, комп'ютерна математика.

Табл.: 1. Рис.: 4. Літ.: 12.

\title{
MATHCAD MATHEMATIC MODELING AS A MEANS OF FORMING THE PROFESSIONAL COMPETENCE OF FUTURE ECONOMISTS
}

\author{
LEVCHUK Olena, \\ Candidate of Pedagogical Sciences, Associate Professor, \\ Associate Professor of the Department of Mathematics, \\ Physics and Computer Technologies, \\ Vinnytsia National Agrarian University
}

(Vinnytsia)

The article substantiates the expediency of introducing mathematical modeling on the basis of Mathcad in the process of forming the professional competence of future economists, defines the main didactic requirements and studies the influence of technology on the main components of mathematical preparation: motivational-value, cognitive, operational-activity, communicative.

It is proved that the process of fundamentalization and informatization of economic knowledge requires transformation of mathematical courses.

The essence of concepts "professional competence" and "mathematical competence" of future economists are considered. It is argued that mathematical training is an important component of professional competence.

The influence of mathematical modeling on the formation of readiness to solve professional problems as a component of professional competence of future economists is analyzed.

The basic mathematical models of economic systems that are expediently considered in mathematical courses are highlighted. Examples of mathematical modeling based on Mathcad are given. 
The advantages of introducing mathematical modeling into the process of professional training of specialists are demonstrated.

Key words: professional training of future economists, mathematical training, Mathcad system, mathematical modeling in economics, higher mathematics, computer mathematics.

Tabl.: 1. Fig.: 4. Ref.: 12.

\title{
МАТЕМАТИЧЕСКОЕ МОДЕЛИРОВАНИЕ НА БАЗЕ МАТНСАD КАК СРЕДСТВО ФОРМИРОВАНИЯ ПРОФЕССИОНАЛЬНОЙ КОМПЕТЕНТНОСТИ БУДУЩИХ ЭКОНОМИСТОВ
}

\author{
ЛЕВЧУК Е.В., \\ кандидат педагогических наук, доцент, \\ доцент кафедры математики, физики и компьютерных технологий, \\ Винницкий национальный аграрный университет
}

(2. Винница)

В статье обоснована иелесообразность внедрения математического моделирования на базе Mathcad в прочессе формирования профессиональной компетентности будущих экономистов, определены основные дидактические требования и исследовано влияние технологии на основные составляющие математической подготовки: мотивационно-ценностную, когнитивную, операционно-деятельностную, коммуникативную.

Доказано, что прочесс фундаментализачии и информатизаџии экономических знаний требует трансформации математических курсов.

Рассмотрены сущность понятий «профессиональная компетентность» и «математическая компетентность» будущих экономистов. Аргументировано, что математическая подготовка является важной составляющей профессиональной компетентности.

Проанализировано влияние математического моделирования на формирование готовности решать профессиональные задачи как составляющей профессиональной компетентности будущих экономистов.

Выделены основные математические модели экономических систем которые целесообразно рассматривать в математических курсах. Приведены примеры математического моделирования на базе Mathcad.

Продемонстрированы преимущества внедрения математического моделирования в процесс профессиональной подготовки спеииалистов.

Ключевые слова: профессиональная подготовка будущих экономистов, математическая подготовка, система Mathcad, математическое моделирование в экономике, высшая математика, компьютерная математика.

Табл.: 1. Рис.: 4. Лит.: 12.

Постановка проблеми. В умовах глобалізаційних процесів професійна діяльність майбутніх економістів характеризується динамічністю, комплексністю та невизначеністю умов. Інформатизація та фундаменталізація знань надають актуальності таким складовим професійної компетентністі майбутнього економіста як здатність аналітично мислити, розв'язувати прогнозні задачі за допомогою програмних продуктів, здійснювати економіко-математичне моделювання 3 використанням сучасних інформаційних систем, застосовувати комп'ютерні технології обробки даних для вирішення економічних завдань [1].

Зазначене надає значимості математичній підготовці як одній із фундаментальних, що в першу чергу формує навички абстрактного мислення, аналізу та синтезу.

У визначенні математичної компетентності програмою міжнародного оцінювання учнів PISA зазначаються не конкретні математичні вміння, а більш загальні уміння, що включають математичне мислення, математичну аргументацію, постановку та розв'язання математичної проблеми, математичне моделювання, використання різних математичних мов, інформаційних технологій, комунікативні вміння [2, с. 47].

Таким чином, виникає нова функція навчального закладу в процесі надання освітніх послуг - формування компетентнісної моделі професійної освіти фахівців.

Сьогодні саме результати математичного моделювання реальних процесів генерують найбільш прогресивні напрямки розвитку в науці і техніці. Тому поняття економіко-математичної моделі відіграє фундаментальну роль у підготовці економістів. Це пояснюється 
міждисциплінарною функцією математики, в тому числі в галузі економічних наук, адже багато економічних законів формулюється не в описовому плані, а саме мовою математики. Сучасний економіст має вільно володіти методами лінійного програмування, динамічного програмування, ігровими методами, методами статистики і теорії ймовірностей.

Тож формування професійної компетентності майбутніх економістів, ураховуючи інтеграцію професійного та особистісного розвитку, має здійснюватися з впровадженням математичного моделювання, починаючи вже з молодших курсів.

Аналіз останніх досліджень і публікацій. О. Новожилова наголошує, що під час викладання математики є необхідною економічна спрямованість, що включає в себе використання та побудову економіко-математичних моделей на базі реальних даних [3].

У цьому сенсі С. Раков розуміє математичну компетентність, як «уміння бачити та застосовувати математику в реальному житті, розуміти зміст і метод математичного моделювання, вміння будувати математичну модель, досліджувати іiі методами математики, інтерпретувати отримані результати, оцінювати похибку обчислень» $[4$, с. 15].

У своєму дослідженні К. Рум'янцева робить висновок, що використання засобів моделювання під час розв'язування творчих фахових завдань у процесі викладання дисципліни “Математика для економістів" дозволяє зацікавити студентів предметом, навчити самих аналізувати, спостерігати, самостійно встановлювати зв'язки і відношення між об'єктами матеріального світу [5, с.11].

Але, незважаючи на те, що математична модель досліджуваного процесу чи явища в економіці є завжди його узагальненим абстрактним відображенням, математичний апарат, який використовується, зазвичай $є$ доволі громіздким. Це $є$ суттєвою перепоною у посиленні прикладної спрямованості математики на перших курсах.

На нашу думку, одним з ефективних шляхів усунення окреслених протиріч $є$ впровадження інформаційних технологій.

У цьому сенсі науковці наголошують на необхідності трансформації відповідних освітніх компонентів на певному рівні вищої освіти в межах спеціальності, зокрема і математичних курсів.

Проблема математичної підготовки майбутніх економістів досліджувалась доволі широко (Г. Булдик, Н. Ванжа, Г. Дутка, Н. Захарченко, В. Клочко, О. Коломок, Л. Мойсеєнко, Л. Нічуговська, І. Новик, О. Новожилова, В. Орлов, С. Раков, Г. Силенок, В. Скатецький, О. Фомкіна). Водночас питання математичного моделювання з використанням інформаційних технологій розглянуто лише частково.

Зокрема, 3-поміж педагогічних умов формування готовності у майбутніх економістів до розв'язування творчих фахових завдань засобами моделювання, виокремлюється комп'ютерне моделювання [5].

О. Семеніхіною обгрунтовано необхідність зміщення акцентів у методиках викладання на формування критичного ставлення учнів до результатів, одержаних знань у процесі вивчення математики на основі електронних освітніх ресурсів [6].

Д. Касаткіним обгрунтовано, побудовано й експериментально перевірено модель підготовки майбутніх економістів до застосування інформаційно-комунікаційних технологій у професійній діяльності. Розроблено зміст навчання економічної інформатики з урахуванням тематичного змісту спеціальних дисциплін [7].

Формулювання цілей статті. Метою нашої публікації є обгрунтування доцільності впровадження математичного моделювання на базі Mathcad у процесі формування професійної компетентності майбутніх економістів, визначення основних дидактичних вимог та дослідження впливу технології на основні складові математичної підготовки: мотиваційно-ціннісну, когнітивну, операційно-діяльнісну, комунікативну.

Виклад основного матеріалу дослідження. У процесі трансформації змісту математичної підготовки ми враховували рівень інтелектуальних умінь першокурсників на рубежі «школа вищий навчальний заклад».

Було виявлено низку проблем, які потребують вирішення:

- нечітке уявлення студентів-першокурсників про майбутню спеціальність;

- труднощі засвоєння навчальної програми, пов'язані з незадовільним базовим рівнем математичної підготовки;

- відсутність зв'язків між абстрактними знаннями та їхнім практичним застосуванням;

- розбіжності очікуваних уявлень з реальними умовами професійної підготовки.

На основі вивченого ми зробили висновок, що для конкретної спеціальності варто виокремлювати професійно значимі теми, питання, поняття класичних розділів математики, які мають своє застосування в професійно-орієнтованих дисциплінах. У лінійній алгебрі - це матриці 
та вектори вартості послуг, норм витрат на перевезення, задачі лінійного програмування. У математичному аналізі - виробничі функції, граничні витрати, продуктивність праці, задачі оптимізації, обсяг продукції. У ймовірнісно-статистичному аналізі - прийняття рішень в умовах невизначеності, теорія вибору вигідної поведінки в умовах конкуренції, резерви підвищення продуктивності праці, контроль якості послуг.

Упровадження 3 першого курсу професійно-орієнтованих завдань, навіть на рівні найпростіших моделей, дозволяє реалізувати принцип наступності в навчанні. Оскільки новий зміст математичних дисциплін стає надійною базою для вивчення спеціальних дисциплін, в межах яких розглядаються вже складніші моделі.

Наприклад, ми розглядаємо матричні та лінійні моделі: модель Леонтьєва багатогалузевої економіки, сукупної реалізації, витрат підприємства, випуску продукції, рівноважних цін, зайнятості у виробництві, техніко-економічну модель виробництва, модель обміну (модель міжнародної торгівлі), витрат виробництва, вартості перевезень, виторгу.

Зокрема, в процесі підготовки фахівців сфери послуг в межах розділу «Лінійна алгебра», розглядаємо модель становлення та розвитку системи екотуризму в певному регіоні, оскільки здобутий математичний апарат використовується в задачах лінійного програмування, яке $\epsilon$ найпоширенішим видом економіко-математичного моделювання. У цьому випадку користуємося математичною моделлю, запропонованою 3. Семеновою, яка має вигляд системи лінійних нерівностей:

$$
\left\{\begin{array}{c}
a_{11} x_{1}+a_{12} x_{2}+\ldots+a_{1 n} x_{n} \leq b_{1} \\
a_{21} x_{1}+a_{22} x_{2}+\ldots+a_{2 n} x_{n} \leq b_{2} \\
\ldots \ldots \ldots \ldots \ldots \ldots \ldots \ldots \ldots \ldots \ldots \ldots . \ldots \ldots \ldots \ldots \ldots \ldots \ldots \ldots \ldots \ldots \ldots \ldots \\
a_{m 1} x_{1}+a_{m 2} x_{2}+\ldots+a_{m n} x_{n} \leq b_{m} \\
x_{1}, x_{2} \ldots x_{n} \geq 0
\end{array},\right.
$$

де $n$ - кількість програм різного виду екотуризму $(n=1,2, \ldots)$;

$x_{j}-$ кількість екотурів, що проводяться по $j$-й програмі;

$a_{i j}$ - рівень зниження $i$-го показника $(i=1,2, \ldots, m)$ екологічного стану середовища (води, повітря, грунтів, флори, фауни) в результаті проведення одного екотуру по $j$-й програмі екологічного туризму;

$b_{i}$ - гранично допустимий рівень зниження відповідного показника середовища;

$X-$ план $\left(x_{1}, x_{2}, \ldots, x_{n}\right)[8]$.

Якщо припустити, що відомі величини $B\left(t_{b}\right)$ - показник стану здоров'я населення в момент часу $t_{b}$ (до того, як почали займатися екотуризмом) та $B\left(t_{a}\right)$ - показник стану здоров'я населення в момент часу $t_{a}$ (після того, як почали займатися екотуризмом), то позитивна динаміка розвитку екологічного туризму можлива за наступних обмежень:

$$
B\left(t_{b}\right) \leq r_{q k} x_{i}, x_{i} \geq 0 ; B\left(t_{b}\right) \leq B\left(t_{a}\right),
$$

$B\left(t_{a}\right) \Rightarrow \max$, де $X_{j}(t)$ - кількість екотурів, що проводяться по $j$-й програмі в період часу $t$; $r_{q k}(t)$ - кількість осіб з покращенням $q$-го показника $(q=1,2, \ldots, s)$ стану здоров'я подорожуючих за $k$-ю $(k=1,2, \ldots, n)$ програмою в період часу $t$.

При реалізації будь-якої кількості $X$, компоненти якого задовольняють систему обмежень (1)-

$$
\text { (2), сумарний прибуток } P \text { визначається цільовою функцією } P(X)=\sum_{k=1}^{n} c_{k} x_{k} \text {, де } c_{k} \text { - прибуток від }
$$
екотуру по $k$-й програмі,

$$
P(X) \Rightarrow \max .
$$

Таким чином, математична модель розвитку екологічного туризму в регіоні, головними пріоритетами якого є збереження особливостей екологічного стану навколишнього середовища та стану здоров'я населення, яке подорожує, визначається системою співвідношень (1)-(3).

Розглянемо конкретну ситуацію з метою здійснення чисельного аналізу. Припустимо, що в певному регіоні реалізується три програми екологічного туризму, зазначені в Таблиці 1. 


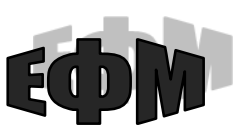

http://efm.vsau.org/

Таблиия 1

Вплив різних програм екологічного туризму

на екологічний стан навколишнього середовища

\begin{tabular}{|c|c|c|c|c|}
\hline \multirow{2}{*}{$\begin{array}{c}\text { Показники } \\
\text { екологічного стану } \\
\text { навколишнього } \\
\text { середовища }\end{array}$} & \multicolumn{2}{|c|}{ Види програм екологічного туризму } & \multirow{2}{*}{$\begin{array}{c}\text { Максимально } \\
\text { допустимі рівні } \\
\text { навантаження на } \\
\text { навколишнс } \\
\text { середовище, \% }\end{array}$} \\
\hline Вода, \% & Актний & Історичний & Агротуризм & 20 \\
\hline Повітря, \% & 0,9 & 0,8 & 0,8 & 15 \\
\hline Грунти, \% & 0,8 & 0,9 & 0,9 & 14 \\
\hline Прибуток (грн) & 5300 & 5000 & 3500 & \\
\hline $\begin{array}{c}\text { Кількість осіб з } \\
\text { покращеним станом } \\
\text { здоров'я в турі, } \\
\text { розрахованому на } 30 \\
\text { осіб }\end{array}$ & 25 & 10 & 28 & \\
\hline
\end{tabular}

Згідно з формулами (1)-(3), ця модель реалізується за допомогою обмежень у вигляді системи лінійних нерівностей та цільової функції, для якої потрібно знайти максимум.

Зазвичай задачі такого типу розв'язуються симплекс-методом, який є доволі громіздким. У процесі математичної підготовки фахівців ми застосовували універсальну інтегровану систему Mathcad, яка дозволяє просто та наочно вводити початкові дані, здійснювати традиційний математичний опис розв'язків та отримувати результати обчислень як в аналітичному вигляді, так і в чисельному з використанням за необхідності графічної інтерпретації. Зазначене дозволило розглянути як найпростіші математичні моделі, так і використати складний математичний апарат, глибше зануритися в суть процесу, не відволікаючись на громіздкі обчислення, розробити універсальні моделі та алгоритми.

Реалізація згаданої моделі в Mathcad дозволяє використати вбудовану функцію Maximize i зразу ж отримати значення змінних, при яких функції набувають максимального значення при заданих обмеженнях (рис. 1).

Отже, оптимальне значення функції прибутку $P(x)=1,028 \times 10^{5}$ досягається в точці 3 координатами: $x_{1}=13,784 ; x_{2}=5,946 ; x_{3}=0$.

Оптимальне значення показника здоров'я населення $B(x)=549,451$ досягається в точці 3 координатами: $x_{1}=9,13 ; x_{2}=0 ; x_{3}=9,565$.

В основі багатьох моделей лежить апарат граничного аналізу, диференціального та інтегрального числення. Це моделі неперервного нарахування відсотків, продуктивності праці, маргінальних витрат, маргінального доходу, еластичності, корисності, визначення максимуму прибутку, оптимального розподілу ресурсів, оптимізації оподаткування підприємства, задача цінової дискримінації, визначення прибутку від виробництва товарів кількох видів, модель обсягу продукції, витрат виробництва, доходів підприємства, нарощування капіталу, дисконтування, надлишок (виграш) споживача, розподілу доходів населення.

Варто зазначити, що в економіко-математичному моделюванні значне місце посідають задачі оптимізації, які вимагають застосування апарату диференціального числення функції однієї та кількох змінних. Як зазначалось раніше, починаємо 3 розгляду найпростіших моделей, які потребують дослідження функції однієї змінної на екстремум. Який об'єм продукції варто випускати, аби забезпечити найвищу рентабельність підприємств? Як організувати транспортні перевезення, мінімізувавши витрати?

Розглянемо моделі оптимізації функціонування, розвитку і розміщення економічних систем, оптимального управління, оптимізації навантажень, які дозволяють знаходити найкращу організаційно-технологічну та просторову структуру з урахуванням міжгалузевих зв’язків.

Часто це вимагає досліджень функції двох чи більше змінних. Наявність вбудованих функцій для знаходження екстремумів в Mathcad дозволяє наочно, швидко та ефективно розв'язати і цю задачу [9, с. 259]. 


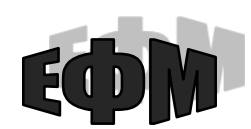

http://efm.vsau.org/

$$
\begin{aligned}
& \mathrm{P}(\mathrm{x} 1, \mathrm{x} 2, \mathrm{x} 3):=5300 \cdot \mathrm{x} 1+5000 \times 2+3500 \times 3 \\
& \mathrm{x} 1:=1 \quad \mathrm{x} 2:=1 \quad \mathrm{x} 3:=1 \\
& \text { Given } \\
& 0.9 \cdot \mathrm{x} 1+0.8 \mathrm{x} 2+0.8 \mathrm{x} 3 \leq 20 \\
& 0.7 \cdot \mathrm{x} 1+0.9 \times 2+0.9 \times 3 \leq 15 \\
& 0.8 \cdot \mathrm{x} 1+0.5 \times 2+0.7 \times 3 \leq 14 \\
& \mathrm{x} 1 \geq 0 \quad \mathrm{x} 2 \geq 0 \quad \mathrm{x} 3 \geq 0 \\
& \left(\begin{array}{l}
\mathrm{x} 1 \\
\mathrm{x} 2 \\
\mathrm{x} 3
\end{array}\right):=\text { Maximize }(\mathrm{P}, \mathrm{x} 1, \mathrm{x} 2, \mathrm{x} 3)=\left(\begin{array}{c}
13.784 \\
5.946 \\
0
\end{array}\right) \\
& \mathrm{x} 1:=13.784 \quad \mathrm{x} 2:=5.946 \quad \mathrm{x} 3:=0
\end{aligned}
$$

\section{Вставка функции}

Категория функции

Интерполяция и предсказание Комплексные числа

Кривая и сглаживание

Кусочно-непрерывные

Логарифм и экспонента

Нанесение графика

Небольшие волны

обработка изображения

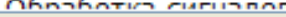

Maximize(f, var1, var2, ...)

Выдаёт значения var1, var2..., которые удовлетворяют ограничениям в Решающем Блоке, и создаёт функцию $\mathrm{f}$, самое большое значение. Выдаёт скаляр, если есть толь параметр, иначе -вектор ответов.
Имя функции

matconv matdeconv matrix

$\max$ Maximize mean medfilt medfilt1d madfit

$\mathrm{P}(\mathrm{x} 1, \mathrm{x} 2, \mathrm{x} 3)=1.028 \times 10^{5}$ - максимальне значення прибутку

[?]

\section{Знаходження максимального значення показника здоров'я населення:}

$\mathrm{B}(\mathrm{x} 1, \mathrm{x} 2, \mathrm{x} 3):=25 \mathrm{x} 1+10 \times 2+28 \times 3$

$\mathrm{x} 1:=1 \quad \mathrm{x} 2:=1 \quad \mathrm{x} 3:=1$

Given

$0.9 \cdot \mathrm{x} 1+0.8 \mathrm{x} 2+0.8 \mathrm{x} 3 \leq 20$

$0.7 \cdot \mathrm{x} 1+0.9 \times 2+0.9 \times 3 \leq 15$

$0.8 \times x 1+0.5 \times 2+0.7 \times 3 \leq 14$

$\mathrm{x} 1 \geq 0 \quad \mathrm{x} 2 \geq 0 \quad \mathrm{x} 3 \geq 0$

$\left(\begin{array}{l}\mathrm{X} 1 \\ \mathrm{X} 2 \\ \mathrm{X} 2\end{array}\right):=\operatorname{Maximize}(\mathrm{B}, \mathrm{x} 1, \mathrm{x} 2, \mathrm{x} 3)=\left(\begin{array}{c}9.13 \\ 0 \\ 9.565\end{array}\right)$ досліджуваній країні.

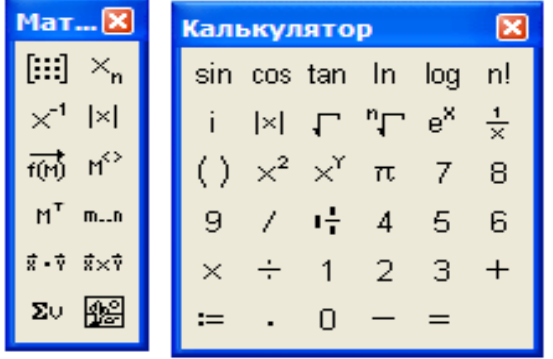

$\begin{array}{cc}\text { Лor... } \mathrm{x} \\ =\leq \\ > & \leq \\ \geq & \neq \\ \neg & \wedge \\ \vee & \oplus\end{array}$

Математика

Добавить

$$
\mathrm{x} 1 \mathrm{M}=9.13 \quad \mathrm{x} 2:=0 \quad \mathrm{x} 3:=9.565
$$

$\mathrm{B}(\mathrm{x} 1, \mathrm{x} 2, \mathrm{x} 3)=496.07$ - максимальне значення показника здоров'я населення

\section{Puc. 1. Робочий документ Mathcad «Математична модель впливу різних програм екологічного туризму на екологічний стан навколишнього середовища» \\ Джерело: сформовано автором за джерелом [8]}

За рахунок такого підходу вирішується проблема ущільнення знань, що дозволяє за вивільнений час розглянути більшу кількість моделей.

Наявність в Mathcad вбудованої функції для знаходження інтегралів аналітично заданих виразів та побудови графіків функцій дозволяє реалізувати моделі, які потребують апарату інтегрального числення. Цікавим є приклад оцінки ступеня нерівномірності розподілу доходів населення. У такому випадку застосовуємо інтегративний підхід на рівні синтезу економічних та математичних понять. Розглядаємо криву Лоренца як функцію однієї змінної $y=f(x)$, де ${ }^{y}-$ частка сукупного доходу, який отримує $x$ населення. Далі вводимо поняття коефіцієнт Джині показник нерівності в розподілі доходів, який дорівнює відношенню площі фігури, що утворюється між кривою Лоренца і лінією абсолютної рівності, до площі трикутника, що утворюється лінією абсолютної рівності і координатними осями (Рис. 2 ).

Досліджуючи криву Лоренца - залежність відсотка доходів від відсотка населення, що їх має, ми можемо оцінити ступінь нерівності в розподілі доходів населення. Достатньо високе значення коефіцієнта Джинні показує істотно нерівномірний розподіл доходів серед населення в

Наприклад, за даними дослідження, в розподілі доходів однієї з країн крива Лоренца описана рівнянням $y(x)=1-\sqrt{1-\mathrm{x}^{2}}$, де $x_{- \text {частка населення, }} y(x)$-частка доходів населення. Обчислити 
коефіцієнт Джинні [10, с. 70].

Розв'язання. Коефіцієнт Джинні обчислюємо, як різницю площ: $K=S_{O A B}=S_{O C B}-S_{O A B C}=1-2\left(1-S_{O A B C}\right)$, де $S_{O A B}$ - площа трикутника зі стороною 1 . Площу криволінійної трапеції ОАВС знаходимо за допомогою означеного інтеграла: $S_{\text {OBAC }}=\int_{0}^{1}\left(1-\sqrt{1-x^{2}}\right) d x=\int_{0}^{1} d x-\int_{0}^{1} \sqrt{1-x^{2}} d x=1-\int_{0}^{1} \sqrt{1-x^{2}} d x$.
$\quad K=1-2\left(1-\int_{0}^{1} \sqrt{1-x^{2}} d x\right)=2 \int_{0}^{1} \sqrt{1-x^{2}} d x-1$
Тому

За допомогою заміни, наприклад, $x=\sin t$ можна обчислити $\int_{0}^{1} \sqrt{1-x^{2}} d x=\frac{\pi}{4}$. Отже, коефіцієнт Джинні $K=2 \cdot \frac{\pi}{4}-1=\frac{\pi}{2}-1 \approx 0,57$.

На Рис. 2 представлено відповідну математичну модель в Mathcad. Універсальність створеної моделі дозволяє розрахувати коефіцієнт Джинні в інших країнах чи в інший час, підставляючи лише нову криву Лоренца $y=f(x)$.



Рис. 2. Робочий документ Мathcad «Оцінка ступеню нерівномірності розподілу доходів населення»

Джерело: сформовано автором за джерелом [10]

За цим підходом важливим $є$ те, що в процесі інтегрування в Mathcad не має суттєвого значення вид підінтегральної функції та рівень складності знаходження відповідного інтегралу. Це дозволяє розширити коло моделей, що розглядаються. Окрім того, використання Mathcad дозволяє яскраво та водночас точно проілюструвати поведінку відповідної функції [9].

В моделях економічної динаміки широко використовуються диференціальні рівняння, в яких існує не лише зв'язок змінних відносно часу, але і їхній взаємозв'язок між собою. Вивчення диференціальних рівнянь починаємо з найпростіших моделей макроекономічної динаміки.

Приклад. Агрофірма реалізує свою продукцію з тижневими перервами, при цьому початкова ціна становить 15 грн за кілограм. Визначити умови рівноваги на ринку, якщо попит $\mathrm{Q}$ та пропозиція S задані наступними функціями: $Q=4 p^{\prime}-2 p+39 ; S=44 p^{\prime}+2 p-1$, де $p$ - ціна на продукцію; $p^{\prime}$ - миттєва швидкість зміни ціни (тенденція зміни ціни). 
Розв'язання: $з$ умови рівноваги на ринку $(Q=S)$ складаємо диференціальне рівняння: $4 p^{\prime}-2 p+39=44 p^{\prime}+2 p-1$. Розв'язавши його відносно $p^{\prime}$, маємо: $p^{\prime}=\frac{10-p}{10}$. Оскільки $p^{\prime}$ - миттєва швидкість, то швидкість зміни ціни за часом $t$ можна подати як відношення диференціалів: $p^{\prime}=\frac{d p}{d t}$, де $p=p(t)$. Тоді маємо диференціальне рівняння з відокремлюваними змінними: $\frac{d p}{d t}=\frac{10-p}{10}$. Проінтегрувавши $\int \frac{d p}{10-p}=\int \frac{d t}{10}$, отримуємо $\ln |p-10|=-\frac{1}{10} t+C$; $p=e^{C} \cdot e^{-\frac{t}{10}}+10=C_{1} \cdot e^{-\frac{t}{10}}+10$ - загальний розв'язок диференціального рівняння.

3 початкових умов $p(0)=15$ знаходимо сталу $C_{1}=5$. Отже, частковий розв'язок рівняння $p(t)=5 \cdot e^{-\frac{t}{10}}+10$ виражає залежність ціни від часу. За умов рівноваги, падіння ціни не вплине на об’єм попиту. Він буде відповідати пропозиції. Вбудовані в Mathcad функції solve та Odesolve дозволяють розв'язати рівняння відносно $p^{\prime}$ та отримати графіки похідної функції ціни $p$ та розв'язку диференціального рівняння (Рис. 3) [9, с. 288].

Проте простежити хід розв'язування диференціального рівняння Mathcad теж дозволяє (Рис. 4). У цьому випадку використовуємо інструменти інтегрування, розв'язування рівнянь та побудови графіка функції [9, С. 217].

До того ж, створена математична модель в Mathcad дає можливість дослідити залежність розв'язку від початкових умов. Тобто проаналізувати вплив початкової ціни на характер іiі зміни в майбутньому.

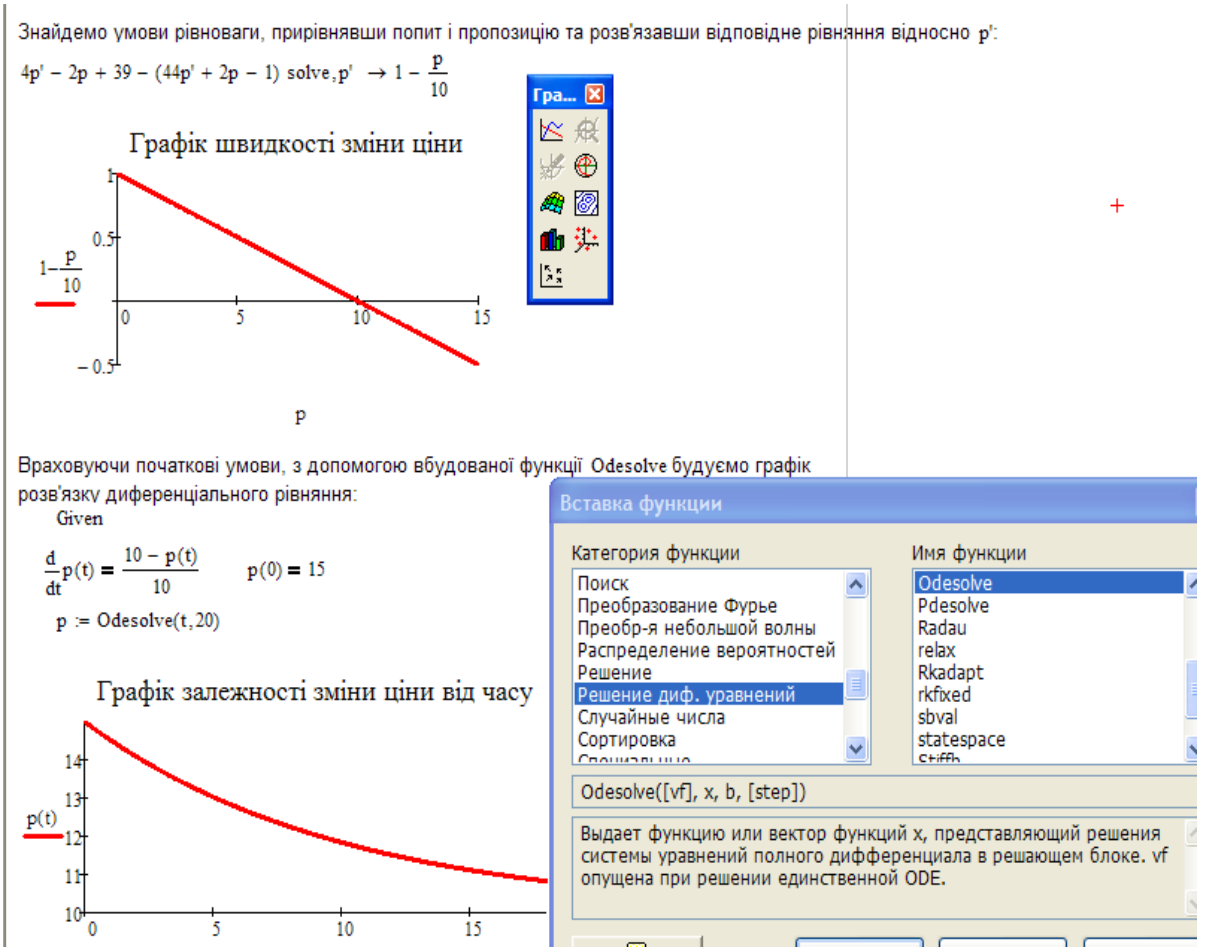

Рис. 3. Робочий документ Mathcad «Розв'язування диференціальних рівнянь 3 використанням будованих функцій solve та Odesolve»

Джерело: сформовано автором

Відповідно до темпу розширення математичного апарату розглядаємо моделі природного зростання випуску продукції, зростання в умовах конкуренції, модель Еванса, динамічну модель Кейнса, неокласичну модель росту, ринку з прогнозованими цінами, зміни фондів підприємства [11, с.12-13]. 
http://efm.vsau.org/

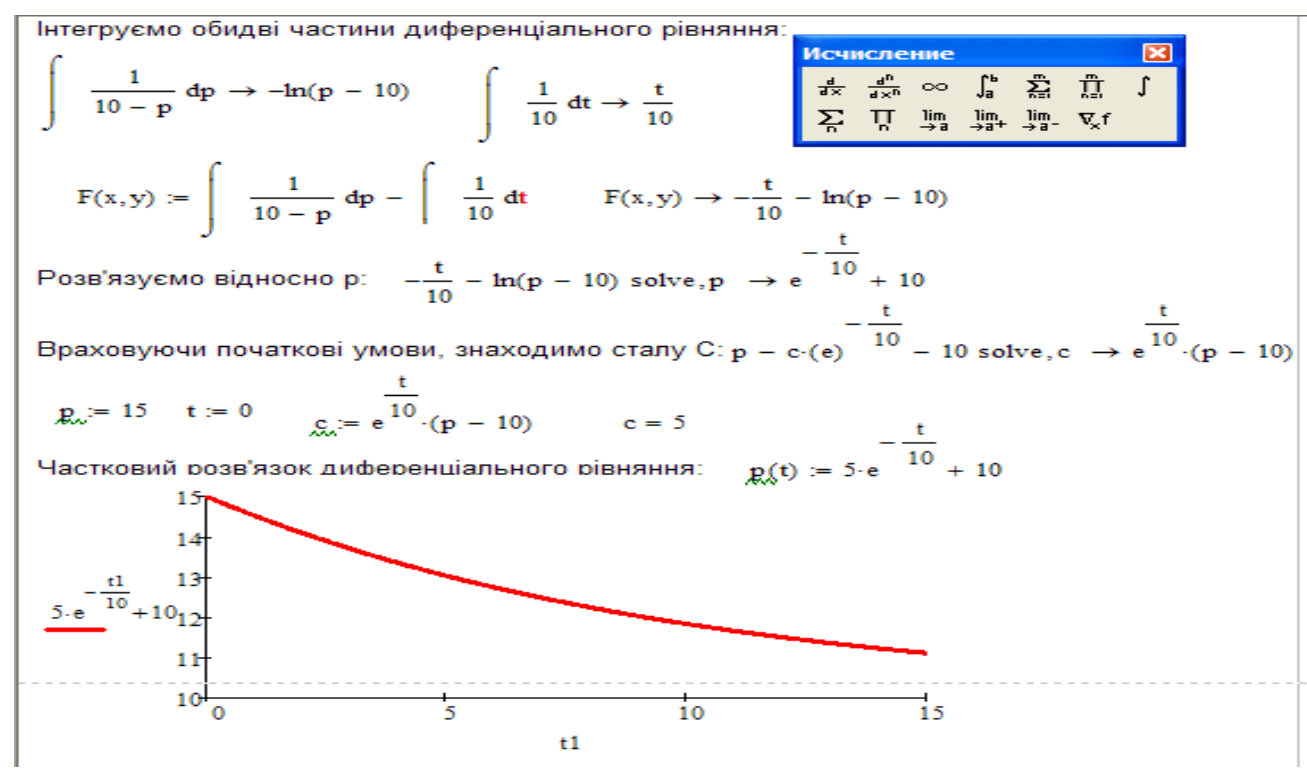

\section{Puc. 4. Робочий документ Mathcad «Розв'язування диференціальних рівнянь з допомогою функції інтегрування» \\ Джерело: сформовано автором}

Висновки. Отож, математичне моделювання на базі Mathcad дозволяє поліпшити основні складові процесу математичної підготовки 3 метою формування професійної компетентності майбутніх фахівців:

- мотиваційно-ціннісний (формування стійкого інтересу до оволодіння математичними знаннями та інформаційними технологіями з метою їхнього застосування в професійній та науководослідній діяльності);

- когнітивний (отримання фундаментальних знань 3 класичних розділів математики та уміння їх застосувати в процесі математичного моделювання);

- операційно-діяльнісний (самореалізація в професійній діяльності засобом математичного моделювання на основі інтеграції знань 3 професійно-орієнтованих та математичних дисциплін 3 використанням інформаційних технологій);

- комунікативний (володіння способами представлення результатів своєї діяльності).

Дослідження показало, що впровадження математичного моделювання має забезпечувати наступні дидактичні вимоги:

- достатньо коректне уявлення викладача про цілісну картину майбутньої навчальної та професійної діяльності студента;

- визначення цілей та призначення введеного нового змісту в зміст математичних дисциплін;

- відповідність навчальної задачі ідеям особистісного підходу (актуалізація особистісних функцій фахівців, узгодженість з проблемами практичного навчання на виробництві);

- апробація вироблених умінь та навичок на практиці.

Таким чином, за рахунок можливості комп'ютерного моделювання при вирішенні професійних завдань усунулися проблеми прогалин в математичній підготовці, що сприяло появі нової якості математичної освіти - фахової спрямованості.

Зазначене дозволяє організувати студентоцентроване навчання та викладання, яке регламентується новими освітніми програмами, застосувати технології проблемного i диференційованого навчання, інтенсифікації та індивідуалізації навчання, програмованого навчання, розвивального навчання, самонавчання, навчання на основі досліджень.

За такого підходу заняття мають інтерактивний характер. Увага акцентується на особистісному розвитку, груповій роботі, умінні презентувати результати роботи, що сприяє формуванню у фахівця розуміння потреби й готовності до продовження самоосвіти впродовж життя [1].

Одним із засобів реалізації підходу у Вінницькому національному аграрному університеті став науково-методичний комплекс дисципліни «Вища та прикладна математика» для фахівців галузі «Сфера обслуговування», який містить: програму дисципліни, електронний посібник, конспект лекцій, методичні вказівки, електронні ресурси (тестові завдання, картка дисципліни в системі «Сократ»), засоби контролю [12]. 


\section{http://efm.vsau.org/}

\section{Список використаних джерел}

1. Каталог освітніх програм підготовки бакалаврів 2018-2019 н.р. Національного університету біоресурсів і природокористування України. TOM 3 URL: https://nubip.edu.ua /node /46601 (дата звернення: 16.03.2019).

2. Основные результаты международного исследования образовательных достижений учащихся PISA-2006 / В. Ю. Баранова, Г. С. Ковалева, Н. Г. Кошеленко, Э. А. Красновский и др. Москва: Центр оценки качества образования ИСМО РАО, 2007. 99 с.

3. Новожилова О.Г. Про розвиток мотивації до вивчення математичних курсів у студентівекономістів. Дидактика математики: пробл. і дослідж.: зб. наук. пр., 2011. Вип. 36. С. 43-47.

4. Раков С. А. Математична освіта: компетентнісний підхід з використанням IКТ: монографія. Харків:Факт, 2005. 360 с.

5. Рум'янцева К.С. Підготовка майбутніх економістів до розв'язування творчих фахових завдань засобами моделювання: автореф. дис. на здобуття наукового ступеня канд. пед. наук: 13.00.04. Вінниця, 2009. 20 с.

6. Семеніхіна О., Шишенко I. Наслідки поширення IT і зміщення акцентів навчання математики у вищій школі. Вища освіта України. 2013. № 4. С. 71-78.

7. Касаткін Д.О. Підготовка майбутніх економістів до застосування інформаційнокомунікаційних технологій у професійній діяльності: автореф. дис. на здобуття наукового ступеня канд. пед. наук: 13.00.04. Ялта, 2011.20 с.

8. Семенова 3. А. Формирование стратегии развития экологического туризма в Российской Федерации: дисс. ... кандидата экономических наук: 08.00.05 / СПб. 2005. 165 с.

9. Плис А.И., Сливина Н.A. Mathcad. Математический практикум для инженеров и экономистов: учеб. пособие. Москва: Финансы и статистика, 2003. 656 с.

10. Левчук О.В., Новицька Л.І. Вища та прикладна математика, методичні вказівки для проведення практичних занять та організації самостійної підготовки здобувачів вищої освіти першого (бакалаврського) освітнього рівня галузі знань - 24 «Сфера обслуговування», Частина II Вінниця: ВНАУ, 2017. 87 с.

11. Бас С.В., Словак, К.І. Збірник компетентнісних математичних задач для студентів економічних спеціальностей : навчальний посібник : спецвипуск «Навчальний посібник у журналі». Том XII. Випуск 1 (32) Кривий Ріг, 2014. 102 с.

12. Електронна система управління «Сократ» URL: http://socrates.vsau.org/ departs/ index.php?id=187\&t_id=456\&mode=cards\&t_name (дата звернення: 16.03.2019).

\section{References}

1. Kataloh osvitnikh prohram pidhotovky bakalavriv 2018-2019 n.r. Natsionalnoho universytetu bioresursiv i pryrodokorystuvannia Ukrainy. Toм 3 [Catalog of educational programs for the preparation of bachelors 2018-2019. National University of Bioresources and Natural Resources of Ukraine. Volume 3] (n.d.). nubip.edu.ua. Retrieved from: https://nubip.edu.ua/node/46601 [in Ukrainian].

2. Baranova,V.Yu., Kovaleva, G.S., Koshelenko, N.G., \& Krasnovskiy, E.A. i dr. (2006). Osnovnyie rezultaty mezhdunarodnogo issledovaniya obrazovatelnykh dostizheniy uchaschihsya PISA-2006 [The main results of the international study of educational achievements of students PISA-2006]. Moskow, Tsentr otsenki kachestva obrazovaniya ISMO RAO, 99 [in Russian].

3. Novozhylova, O.H. (2011). Pro rozvytok motyvatsii do vyvchennia matematychnykh kursiv u studentivekonomistiv [On the development of motivation to study mathematical courses at student economists.]. Dydaktyka matematyky: probl. i doslidzh-Didactics of Math: Probl. and research, Vol. 36, pp. $43-47$ [in Ukrainian].

4. Rakov, S.A. (2005). Matematychna osvita: kompetentnisnyi pidkhid z vykorystanniam IKT [Mathematical Education: A Competency Approach Using ICT]. Kharkiv, Fakt, 360 [in Ukrainian].

5. Rumiantseva, K.Ye. (2009). Pidhotovka maibutnikh ekonomistiv do rozviazuvannia tvorchykh fakhovykh zavdan zasobamy modeliuvannia [Training of future economists for solving creative tasks by means of modeling]. Extended abstract of candidate's thesis. Vinnytsia, 20 [in Ukrainian].

6. Semenikhina, O., \& Shyshenko, I. (2013). Naslidky poshyrennia IT i zmishchennia aktsentiv navchannia matematyky u vyshchii shkoli. Vyshcha osvita Ukrainy [Consequences of the spread of IT and shifting the emphasis of teaching mathematics to higher education]. Vyshcha osvita Ukrayini - Higher education in Ukraine, 4, 71-78 [in Ukrainian].

7. Kasatkin, D. O. (2011). Pidhotovka maibutnikh ekonomistiv do zastosuvannia informatsiinokomunikatsiinykh tekhnolohii u profesiinii diialnosti [Training of future economists for application of information and communication technologies in professional activity]. Extended abstract of candidate's thesis. Yalta, 20 [in Ukrainian]. 
8. Semenova, Z.A. (2005). Formirovaniye stratehii razvitiya ekologicheskogo turizma v Rossyiskoi Federatsyy [Formation of a strategy for the development of ecological tourism in the Russian Federation]. Candidate's thesis. St. Peterburg, 165 [in Russian].

9. Plys, A.Y. \& Slyvyna N.A. (2003). Mathsad. Matematycheskyi praktykum dlia inzhenerov i ekonomistov: ucheb. posobiye. [Mathsad. Mathematical Workshop for Engineers and Economists]. Moskow, Finansyi i statistika, 656 [in Russian].

10. Levchuk, O.V., \& Novytska, L.I. (2017). Vyshcha ta prykladna matematyka, metodychni vkazivky dlia provedennia praktychnykh zaniat ta orhanizatsii samostiinoi pidhotovky zdobuvachiv vyshchoi osvity pershoho (bakalavrskoho) osvitnoho rivnia haluzi znan - 24 «Sfera obsluhovuvannia» [Higher and Applied Mathematics, methodical instructions for conducting practical classes and organization of independent training of applicants of higher education of the first (Bachelor) educational level of the field of knowledge - 24 "Sphere of service"], part 2, Vinnytsia, VNAU, 87 [in Ukrainian].

11. Bas, S.V. \& Slovak, K. I. (2014). Zbirnyk kompetentnisnykh matematychnykh zadach dlia studentiv ekonomichnykh spetsialnostei [Collection of competency mathematical problems for students of economic specialties]. Special Edition, Vol. III, Issue 1 (32). Kryvyi Rih, 102 [in Ukrainian].

12. Elektronna systema upravlinnya «Sokrat» [Electronic control system "Socrates"] (n.d.). socrates.vsau.org. Retrieved from: http://socrates.vsau.org/departs/ index.php?id=187\&t_id= 456\&mode=cards\&t_name [in Ukrainian].

\section{Інформація про автора}

ЛЕВЧУК Олена Володимирівна - кандидат педагогічних наук, доцент, доцент кафедри математики, фізики та комп'ютерних технологій, Вінницький національний аграрний університет (21008, м. Вінниця, вул. Сонячна, 3, e-mail: olena_levcukk@ukr.net).

LEVCHUK Olena - Candidate of Pedagogical Sciences, Associate Professor, Associate Professor of the Department of Mathematics, Physics and Computer Technologies, Vinnytsia National Agrarian University. (21008, Vinniysia, 3 Soniachna Str., e-mail: olena_levcukk@ukr.net).

ЛЕВЧУК Елена Владимировна - кандидат педагогических наук, доцент, доцент кафедры математики, физики и компьютерных технологий, Винницкий национальный аграрный университет (г. Винница, ул. Солнечная, 3, e-mail: olena_levcukk@ukr.net).



УАК 004.942:330.43

\begin{tabular}{l|r} 
& $\begin{array}{r}\text { VOLONTYR Ludmila, } \\
\text { ECONOMETRIC MODELING IN } \\
\text { FORMATION OF OPTIMAL PRICE FOR } \\
\text { IMPLEMENTATION OF } \\
\text { AGRICULTURAL PRODUCTS }{ }^{\odot}\end{array}$ POTAPOVA Oksana, \\
& Department of Computer Science \\
and Economic Cybernetics \\
Vinnytsia National Agrarian University, \\
(Vinnytsia, Ukraine)
\end{tabular}

The relevance of the research topic is due to the fact that recently prices for agricultural products and in particular fish, meat and especially vegetables in Ukraine, show considerable instability and variability, and predicting the price on the basis of such data is difficult enough.

It is well known that in market conditions the price level is determined by the ratio of the demand and supply. At the same time, in conditions of the modern agricultural market, imperfect and not efficient enough, the price of agricultural products is significantly influenced by farm factors, which prevent agricultural commodity producers from developing the maximum possible selling prices for finished products. Recently, the situation on the vegetable market has changed: the demand and supply sharply reduced, rates of decline in demand become prevailing, and in particular due to a significant increase in prices. At the same time, many types of scarce vegetable products have become over-saturated. The decrease in the demand for vegetable products is primarily due to the decrease in household incomes, as 